\title{
Does the Financial Performance of Companies Listed in the Jakarta Islamic Index Change, When Implementing IFRS Accounting Standards?
}

\author{
Muhammad Sholahuddin ${ }^{1}$, Adi Parkawati ${ }^{2}$ \\ muhammad.sholahuddin@ums.ac.id', adiparka5@gmail.com²
}

Program Studi Manajemen, Fakultas Ekonomi dan Bisnis, Universitas Muhammadiyah Surakarta ${ }^{1,2}$

\begin{abstract}
The International Financial Reporting Standard (IFRS) is a change in the rules of accounting standards that affects the international accounting information environment. IFRS financial accounting standards in Indonesia apply to companies or institutions that have listed their business entities on the IDX as well as business entities that have public accountability. The purpose of this study is to analyze differences in financial performance as measured by liquidity ratios, solvency, and profitability before and after the company converts to IFRS. This study is a comparative study comparing financial statements using purposive sampling techniques to produce five companies that are continuously listed in the Jakarta Islamic Index for the period 2008 - 2017 with a data analysis method in the form of the Wilcoxon test because the data normality test is not normal. The results of this study indicate that liquidity ratios measured using the current ratio $(\mathrm{CR})$ and solvency ratios measured using DER and DAR have no significant difference between before and after conversion to IFRS.
\end{abstract}

Keywords: IFRS; liquidity ratio; solvency ratio; profitability ratio; JII

\section{Introduction}

Perekonomian global membawa tantangan baru untuk akuntan yang menyusun laporan keuangan karena para pemakai informasi akuntansi membutuhkan informasi laporan keuangan internasional yang berkualitas [1]. Setiap negara memiliki standar akuntansi berbeda yang disesuaikan dengan kebutuhan negaranya. Untuk meningkatkan kualitas laporan keuangan, perlu adanya standar akuntansi berstandar internasional yang berlaku untuk peraturan pelaporan dan mengurangi biaya pelaporan keuangan perusahaan multinasional [2].

Sekarang ini di dunia terdapat dua standar yang digunakan atau diadopsi dalam menyususn laporan keuangan, yaitu IFRS (International Financial Reporting Standard) yang diterbitkan International Accounting Standard Board dan Prinsip Akuntansi Berterima Umum (Generally Accepted Accounting Principles) yang diterbitkan oleh FASB (Financial Accounting Standard Board). Oleh karena adanya keinginan untuk menyusun satu standar akuntansi internasional yang berkualitas, banyak negara yang sudah mengadopsi penuh IFRS [11]. Standar Akuntansi IFRS yang ada di Indonesia diberlakukan untuk perusahaan atau lembaga yang akan atau sudah mencatatkan badan usahanya di Bursa Efek Indonesia serta badan usaha yang memiliki pertanggungjawaban kepada masyarakat [1].

Penerapan IFRS di Indonesia diperkirakan dapat memberikan manfaat terhadap peningkatan kualitas pelaporan keuangan, seperti yang terjadi di negara-negara Eropa.Selain 
itu, Indonesia dikhawatirkan kurang siap menerima IFRS dikarenakan kurang siapnya Dewan Standar Akuntansi Keuangan sebagai financial accounting standard setter Indonesia, kondisi perpu yang belum tentu sinkron dengan IFRS, serta kurangnya sumber daya manusia yang memadai. Dampak negatif ini dikhawatirkan akan memengaruhi kualitas laporan keuangan yang seharusnya dapat menunjukkan peningkatan menjadi stagnan atau bahkan menurun setelah melakukan implementasi pengadopsian IFRS [5].

Penelitian yang membahas mengenai studi komparatif dan pengimplementasian kinerja keuangan sebelum dan sesudah mengadopsi IFRS sudah dilakukan oleh beberapa peneliti dan menunjukkan hasil penelitian yang berbeda satu sama lain. Penelitian berjudul Accounting Quality: Differences Before and After IFRS-adoption in Europe [10], menunjukkan bahwa pada periode sebelum mengadopsi IFRS, kualitas akuntansi perusahaan di negara dengan sistem hukum yang berorientasi pada perencanaan (code-law countries) berbeda secara signifikan dari kualitas akuntansi perusahaan di negara yang berorientasi pada pasar (commonlaw countries) meskipun signifikansinya tidak berlaku disemua metrik. Diperiode setelah mengadopsi IFRS, perbedaannya tidak signifikan disetiap metrik.Hal ini berarti, setelah IFRS diadopsi, kualitas laporan keuangan lebih pada tingkat yang sama di negara-negara yang diteliti. Sementara itu, penelitian di Rumania mengenai dampak dari pengadopsian IFRS [8] menunjukkan tidak adanya perbedaan yang signifikan secara statistik terhadap median dan rata-rata tingkat yang diamati. Relevansi dapat diidentifikasi pada variasi-variasi dengan mempertimbangkan rasio solvabilitas dan laba atas ekuitas.

Penelitian ini akan fokus terhadap perbedaan kinerja keuangan perusahaan yang diukur melalui rasio likuiditas, solvabilitas, dan profitabilitas sebelum maupun sesudah perusahaan tersebut mengonversi ke Standar Akuntansi Keuangan IFRS pada perusahaan yang secara terus-menerus terdaftar di Jakarta Islamic Index pada periode 2008-2017.

\section{Metode}

Penelitian ini termasuk penelitian komparatif, yaitu penelitian yang membandingkan laporan keuangan dari tahunketahun dalam jumlah absolut (rupiah) maupun persentase, sedangkan untuk jangka waktu yang lebih lama menggunakan tren [9]. Data penelitian ini termasuk kedalam data sekunder, yaitu data laporan keuangan berupa ICMD (Indonesia Caapital Market Directory) dari perusahaan tercatat dalam Bursa Eek Indonesia (BEI) periode 2008-2017 yang diperoleh dari website resmi Bursa Efek Indonesia, yaitu www.idx.co.id. Penelitian ini menggunakan pendekatan kuantitatif karena data utamanya berupa laporan keuangan yang berbentuk angka.

Teknik purposive sampling merupakan teknik yang digunakan untuk pengambilan sampel dalam penelitian ini.Kriteria sampel penelitian yaitu perusahaan yang secara terusmenerus terdaftar di JII periode 2008-2017 dan memiliki laporan keuangan yang lengkap. Berdasarkan hal tersebut, perusahaan yang sesuai dengan kriteria yang sudah ditentukan dan dapat dijadikan sampel sebanyak 5 perusahaan yaitu AALI, KLBF, SMGR, TLKM, dan UNVR dari 83 perusahaan yang tidak sesuai dengan kriteria. Metode analisis berupa uji Wilcoxon, yaitu uji nonparametris yang digunakan untuk mengetahui signifikansi dari perbedaan dua kelomok data berpasangan berskala ordinal atau interval, tetapi berdistribusi tidak normal [5]. 


\section{Hasil dan Pembahasan}

\subsection{Uji Statistik Deskriptif}

\section{a. Rasio Likuiditas}

Rata-rata current ratio (CR) sebelum konversi IFRS menunjukkan hasil yang lebih tinggi dibanadingkan dengan sesudah konversi IFRS (240.9533 > 224.3642). Artinya, rasio likuiditas yang diukur menggunakan CR sebelum konversi IFRS kinerja keuangan perusahaan tersebut lebih baik dibandingkan dengan sesudah konversi IFRS.

\section{b. Rasio Solvabilitas}

Rata-rata debt to assets ratio (DAR) sebelum maupun sesudah konversi IFRS hasilnya relatif rendah, di bawah 1.00 (0.3008 dan 0.3696), sedangkan rata-rata debt to equity ratio (DER) sebelum maupun sesudah konversi IFRS juga menghasilkan rata-rata yang rendah, di bawah 1.00 (0.5554 dan 0.6938), artinya rasio solvabilitas yang diukur menggunakan DAR sebelum dan sesudah konversi IFRS menunjukkan bahwa kinerja keuangan perusahaan tersebut dalam kondisi baik, sedangkan yang diukur dengan DER menunjukkan bahwa sumber modal perusahaan tidak tergantung dengan kreditur.

\section{c. Rasio Profitabilitas}

Rata-rata ROA sebelum konversi IFRS menghasilkan nilai yang lebih tinggi dibandingkan sesudah konversi IFRS $(23.1442>19.9438)$. Hal ini berarti efiensi manajemen asset perusahaan lebih baik sebelum konversi IFRS daripada sesudah konversi IFRS. Sementara itu, rata-rata $\mathrm{ROE}$ juga menunjukkan hasil yang lebih baik sebelum konversi IFRS dibandingkan sesudah konversi IFRS dengan selisih 1.8325. ROE ini menunjukkan ukuran dalam memperoleh profit untuk pemegang saham.

Tabel 3.1 Nilai Uji Statistik Deskriptif

\begin{tabular}{|c|c|c|c|}
\hline \multirow[t]{2}{*}{ Rasio } & & $\begin{array}{l}\text { Sebelum } \\
\text { Konversi } \\
\text { IFRS }\end{array}$ & $\begin{array}{l}\text { Sesudah } \\
\text { Konversi } \\
\text { IFRS }\end{array}$ \\
\hline & & $\begin{array}{l}\text { Mean/ } \\
\text { Rata-Rata }\end{array}$ & $\begin{array}{l}\text { Mean/ } \\
\text { Rata-rata }\end{array}$ \\
\hline Likuiditas & $\mathrm{CR}$ & 240.9533 & 224.3642 \\
\hline \multirow[t]{2}{*}{ Solvabilitas } & DAR & 0.3008 & 0.3696 \\
\hline & DER & 0.5554 & 0.6938 \\
\hline \multirow[t]{2}{*}{ Profitabilitas } & ROA & 23.1442 & 19.9438 \\
\hline & ROE & 37.845 & 36.0125 \\
\hline
\end{tabular}

\subsection{Uji Normalitas}

Syarat utama sebelum melakukan paired sample t-test yaitu penyebaran data penelitian harus normal dikarenakan paired sample t-test termasuk statistic parametric, yang memberitahu apakah data berdistribusi normal atau tidak dilakukan dengan uji 
normalitas.Berikut hasil uji normalitas dengan menggunakan SPSS. Interpretasi hasil uji normalitas:

(1) Current Ratio, Asymp. Sig (2-tailed) $0.002<0.050$ yang artinya data tersebut tidak berdistribusi normal,

(2) DAR, Asymp.Sig. (2-tailed) $0.001<0.050$ yang artinya data tersebut tidak berdistribusi normal,

(3) DER, Asymp. Sig. (2-tailed) $0.000<0.050$ yang artinya data tersebut tidak berditribusi normal,

(4) ROA, Asymp. Sig. (2-tailed) $0.000<0.050$ yang artinya data tersebut tidak berdistribusi normal, dan

(5) ROE, Asymp. Sig (2-tailed) $0.000<0.050$ yang artinya data tersebut tidak berdistribusi normal.

Jadi, kesimpulannya data yang digunakan dalam penelitian ini tidak berdistribusi normal.

\begin{tabular}{|c|c|c|c|c|c|c|}
\hline & & $\mathrm{CR}$ & DAR & DER & $\mathrm{ROA}$ & ROE \\
\hline \multicolumn{2}{|l|}{$\mathrm{N}$} & 48 & 48 & 48 & 48 & 48 \\
\hline \multirow{2}{*}{$\begin{array}{l}\text { Norm } \\
\text { al }\end{array}$} & \multirow{2}{*}{ Mean } & 232 . & .335 & .624 & 21.544 & 36.9 \\
\hline & & 6587 & 2 & 6 & 0 & 287 \\
\hline Para & Std. & 177. & .204 & .570 & 11.623 & 30.4 \\
\hline meter & Deviati & 7536 & 50 & 38 & 10 & 0054 \\
\hline $\mathrm{S}^{\mathrm{a}, \mathrm{b}}$ & on & 2 & & & & \\
\hline $\begin{array}{l}\text { Most } \\
\text { Extre }\end{array}$ & $\begin{array}{l}\text { Absolu } \\
\text { te }\end{array}$ & .168 & .171 & .239 & .206 & .369 \\
\hline $\begin{array}{l}\text { me } \\
\text { Differ }\end{array}$ & Positiv & .168 & .171 & .239 & .206 & .369 \\
\hline $\begin{array}{l}\text { Dinces } \\
\text { ences }\end{array}$ & $\begin{array}{l}\text { Negati } \\
\text { ve }\end{array}$ & -.145 & -.146 & -.193 & -.158 & -.225 \\
\hline \multicolumn{2}{|c|}{ Test Statistic } & .168 & .171 & .239 & .206 & .369 \\
\hline \multicolumn{2}{|c|}{$\begin{array}{l}\text { Asymp. Sig. } \\
\text { (2-tailed) }\end{array}$} & $.002^{c}$ & $.001^{c}$ & $.000^{\circ}$ & $.000^{c}$ & $.000^{\circ}$ \\
\hline
\end{tabular}

Sumber: olah data uji normalitas dengan

SPSS, 2019

\subsection{Uji Wilcoxon}

Oleh karena hasil uji normalitas menunjukkan distribusi data yang tidak normal, jadi tidak bisa menggunakan statistik parametrik paired sample t-test sehingga harus menggunakan statistik nonparametrik uji Wilcoxon.

Tabel 3.3 Hasil Uji Wilcoxon 


\begin{tabular}{lcrrrr} 
& Pasca & Pasc & Pasc & Pasc & Pasc \\
& $\begin{array}{l}\text { Curren } \\
\text { tRatio }\end{array}$ & a & a & a & a \\
& - Pre & DAR & DER & ROA & ROE \\
& Curren & - Pre & - Pre & - Pre & - Pre \\
& DAR & DER & ROA & ROE \\
\hline tRatio & & & & \\
\hline & -1.286 & - & - & - & - \\
& & 1.90 & 1.68 & 2.05 & 2.02 \\
Asymp & .199 & .057 & .092 & .040 & .042 \\
. Sig. & & & & & \\
(2- & & & & & \\
tailed) & & & & & \\
\hline
\end{tabular}

Sumber: olah data uji Wilcoxon dengan SPSS, 2019

Keterangan:

Pasca - sebelum konversi ke IFRS

Pre - setelah konversi ke IFRS

Hasil dari uji Wilcoxon yaitu:

(1) Current Ratio, memperoleh hasil dari Asymp. Sig. (2-tailed) $0.199>0.050$ artinya Current Ratio tidak memilii perbedaan yang signifikan antara sebelum dan sesudah konversi IFRS (H1 ditolak),

(2) DAR, memperoleh hasil dari Asymp. Sig. (2-tailed) $0.057>0.050$ artinya DAR tidak memiliki perbedaan yang signifikan antara sebelum dan sesudah konversi IFRS (H2 ditolak),

(3) DER, memperoleh hasil dari Asymp. Sig. (2-tailed) $0.092>0.050$ artinya DER tidak memiliki perbedaan yang signifikan antara sebelum dan sesudah konversi IFRS (H2 ditolak),

(4) ROA, memperoleh hasil dari Asymp. Sig. (2-tailed) $0.040<0.050$ artinya ROA memiliki perbedaan yang signifikan antara sebelum dan sesudah konversi IFRS (H3 diterima),

(5) ROE, memperoleh hasil dari Asymp. Sig. (2-tailed) $0.042<0.050$ artinya ROE memiliki perbedaan yang signifikan antara sebelum dan sesudah konversi IFRS (H3 diterima).

\section{KESIMPULAN}

Berdasarkan hasil penelitian yang menguji perbedaan kinerja keuangan yang terdaftar di JII sebelum (periode 2008-2011) dan sesudah (periode 2012-2015) konversi ke IFRS, maka dapat disimpulkan bahwa hasil uji data menggunakan analisis data nonparametrik uji Wilcoxon menunjukkan:

1) Rasio likuiditas yang diukur dengan current ratio tidak memiliki perbedaan yang signifikan sebelum maupun sesudah konversi ke IFRS,

2) Rasio solvabilitas yang diukur dengan DER dan DAR tidak memiliki perbedaan yang signifikan sebelum maupun sesudah konversi ke IFRS, 
3) Rasio profitabilitas yang diukur menggunakan ROA dan ROE menunjukkan perbedaan yang signifikan sebelum maupun sesudah konversi ke IFRS, hasil ini sesuai penelitian yang dilakukan oleh [3].

\section{References}

[1]Procházka, D.: "Specifics of IFRS Adoption by Czech Private Companies. Procedia - Social and Behavioral Sciences “. 220(March), 363-372. https://doi.org/10.1016/j.sbspro.2016.05.510 (2016)

[2]Yurisandi, T., \& Puspitasari, E.: "Financial Reporting Quality - Before and After IFRS Adoption Using NiCE Qualitative Characteristics Measurement. Procedia - Social and Behavioral Sciences, "211, 644-652. https://doi.org/10.1016/j.sbspro.2015.11.091 (2015)

[3]Ghani, M. R.: "Analisis Perbandingan Rasio Profitabilitas Laporan Keuangan Sebelum dan Sesudah Penerapan International Financial Reporting Standards (IFRS)“. Skripsi (2012)

[4]Handayani, Y. P.: “Analisis Perbedaan Manajemen Laba Laba Sebelum dan Sesudah Penerapan Standar Akuntansi Keuangan ( Konvergensi IFRS)“. Skripsi (2014)

[5]Hariyani, R., \& Martini.: "Analisis Komparatif Kualitas Informasi Akuntansi dan Kinerja Keuangan Sebelum dan Sesudah Penerapan International Financial Reporting Standard“. 4(2), 1-16. https://doi.org/10.5199/ijsmart-1791-874X-19c (2015)

[6]King, R. A.: "Effect of IFRS Adoption on Reporting Quality in Kenya". 17(1), 82-84. https://doi.org/10.9790/487X-17118284 (2015)

[7]Liu, F., Hsu, H., \& Yen, D. $\quad$ C.: $\quad$ SC. "Information \& Management".https://doi.org/10.1016/j.im.2018.04.002 (2018)

[8]Munteanu, A., Brad, L., Ciobanu, R., \& Dobre, E.: "IFRS Adoption in Romania: The Effects upon Financial Information and its Relevance. Procedia Economics and Finance". 15(14), 288-293. https://doi.org/10.1016/S2212-5671(14)00504-8 (2014)

[9]Rouhuo, N. C., Douagi, W. B. M., \& Hussainey, K.: "The Effect of IFRS Enforcement Factors on Analusts' Earnings Forecasts Accuracy “.Accounting Forum. 39(5), 561-563 (2008)

[10]Sondagh, T.: "Accounting Quality: Differences before and after IFRS-adoption in Europe Masterthesis in Accounting "(2011)

[11]Yusrina, H., Mukhtaruddin, M., Fuadah, L., \& Sulong, Z.: "International Financial Reporting Standards Convergence and Quality of International Financial Reporting Standards Convergence and Quality of Accounting Information: Evidence from Indonesia. International Journal of Economics and Financial Issues “.(January) (2017) 